\title{
Analisis Tingkat Pencemaran Air Sungai Berdasarkan Kadar Fluorida Di Kota Mataram Menggunakan Metode Spektrofotometri UV-Vis
}

\author{
Kholik Hidayatullah $^{1 *}$, Siti Alaa'2) ${ }^{2}$ Hasmiyatni $^{3}$, Dian Wijaya Kurniawidi ${ }^{4}$ \\ 1,2,4Program Studi Fisika FMIPA Universitas Mataram, Indonesia \\ ${ }^{3}$ Balai Laboratorium Kesehatan, Pengujian dan Kalibrasi Provinsi NTB, Indonesia \\ ${ }^{*}$ Koresponden Penulis : kholik1741@gmail.com
}

\begin{abstract}
ABSTRAK
Tingkat pencemaran air sungai dapat dianalisis salah satunya berdasarkan kadar fluorida. Kadar fluorida yang berlebihan akan menyebabkan terjadinya fluorosis pada tulang. Sedangkan kekurangan fluorida akan menyebabkan kerapuhan pada gigi dan penipisan tulang. Tujuan penelitian ini adalah untuk mengetahui tingkat pencemaran air sungai berdasarkan kadar fluorida di Kota Mataram. Pengujian kadar fluorida dilakukan dengan menambahkan larutan zirconil alizarin sebagai reagen dan larutan $\mathrm{Na}$ arsenit, yang kemudian diuji secara spektrofotometri UV-Vis dengan panjang gelombang $535 \mathrm{~nm}$. Hasil penelitian menunjukkan bahwa kadar fluorida pada 7 sampel yang diuji telah memenuhi standar baku mutu fluorida. Kadar fluorida tertinggi terdapat pada sampel 2 dan sampel 4 sebesar 1,046 mg/L, sedangkan kadar fluorida terendah terdapat pada sampel 6 dan sampel 7 sebesar 0,213 mg/L. Dari penelitian ini dapat disimpulkan bahwa dari 7 titik lokasi pengambilan sampel air sungai di Kota Mataram tidak tercemar fluorida.
\end{abstract}

Kata kunci: Fluorida, pencemaran air, spektrofotometri $U V$-Vis

\section{ABSTRACT}

River water pollution levels can be analysed based on fluoride levels. Excessive fluoride levels will cause fluorosis of the bones. While fluoride deficiency will cause brittleness of teeth and thinning of bones. This study has a purpose to determine the level of river water pollution based on fluoride levels in Mataram City. Fluoride levels were tested by adding a solution of zirconyl alizarin as a reagent and a solution of Na arsenite, which was then analysed by $U V$-Vis spectrophotometry with a wavelength of $535 \mathrm{~nm}$. The results showed that the fluoride levels in the 7 tested samples met the fluoride quality standards. The highest fluoride content of river water in Mataram city is $1.046 \mathrm{mg} / \mathrm{L}$, while the lowest is $0.213 \mathrm{mg} / \mathrm{L}$. From this study it can be concluded that based from 7 points location water river sample in Mataram City are not polluted by fluoride.

Keywords:Fluoride, water pollution, UV-Vis spectrophotometry

doi: 10.33474/e-jbst.v7i2.482

Diterima tanggal 3 Desember 2021- Diterbitkan Tanggal 29 Januari 2022

http://creativecommons.org/licenses/by/4.0 
e-Jurnal Ilmiah BIOSAINTROPIS (BIOSCIENCE-TROPIC)

Volume 7/ No.: 2 / Halaman 119 - 125 / Januari Tahun 2022

ISSN : 2460-9455 (e) - 2338-2805(p)

\section{Pendahuluan}

Wilayah Kota Mataram sebagian besar merupakan dataran rendah, sedang dan di sebelah utara berupa dataran perbukitan dan pegunungan. Kota Mataram terletak pada ketinggian 75 mdpl dengan luas area $6130 \mathrm{Ha}$. Secara geografis, Kota Mataram terletak di ujung barat Pulau Lombok pada titik koordinat $116^{\circ} 04^{\prime}-116^{\circ} 10^{\prime}$ Bujur Timur dan $08^{\circ} 33^{\prime}-08^{\circ} 38^{\prime}$ Lintang Selatan. Bentuk wilayah Kota Mataram sebagian besar landai (75.89\%) dan dilewati oleh empat buah sungai yaitu Sungai Jangkok $(10.500 \mathrm{~m})$ Sungai Ancar $(12,400 \mathrm{~m})$, Sungai Unus $(11.600 \mathrm{~m})$ dan Sungai Brenyok $(4.800 \mathrm{~m})$. Keberadaan keempat sungai tersebut menjadi lahan budidaya kangkung bagi sebagian masyarakat sekitar. Terhitung terjadi peningkatan produksi kangkung sebanyak 24,5\% dari tahun 2019-2020 [1]. Namun, seiring peningkatan jumlah penduduk dan perkembangan Kota Mataram, terjadi pola perubahan konsumsi masyarakat yang cukup tinggi, ditambah dengan luas lahan yang tetap dapat mengakibatkan tekanan terhadap lingkungan meningkat.

Aktivitas masyarakat dalam memenuhi kebutuhan hidup yang berasal dari aktivitas industri, pertanian, dan kegiatan rumah tangga akan menghasilkan limbah yang berdampak pada penurunan kualitas air sungai. Tercatat produksi sampah di Kota Mataram meningkat 1,84\% dari tahun 2019 sebanyak 340.700,5 $\mathrm{m}^{3}$ menjadi $346.976,7 \mathrm{~m}^{3}$ di tahun 2020. Jika dibiarkan begitu saja, keadaan tersebut akan berdampak pada pencemaran dan penurunan kualitas air sungai. Menurut Wiriani [2] air dengan kualitas yang buruk dapat mempengaruhi kesehatan dan keselamatan makhluk hidup serta mencemari lingkungan sekitar. Selain itu, dapat menyebabkan kondisi lingkungan menjadi buruk. Pencemaran air adalah berubahnya komposisi air oleh aktivitas manusia sehingga dapat menyebabkan kualitas air menjadi buruk atau tidak dapat digunakan lagi sebagaimana fungsinya [3]. Pencemaran air sungai ditentukan oleh menurunnya kualitas air sungai sampai ke tingkat tertentu. Hal tersebut dapat diketahui sesuai dengan standar baku mutu air sungai yang telah ditetapkan. Tingkat pencemaran air sungai dapat diketahui melalui beberapa parameter fisika, kimia, dan biologi. Salah satu parameter kimia yang menjadi acuan dari analisis kualitas air sungai adalah fluorida. Secara alamiah, fluorida dalam air berasal dari degradasi mineral persenyawaan fluorida pada air tanah [4].

Fluorida merupakan unsur yang paling elektronegatif sehingga memiliki kecenderungan yang kuat untuk menjadi gas negatif dan ion F di dalam larutan [5]. Fluorida menjadi unsur yang paling banyak digunakan dalam pencegahan karies gigi karena beberapa penelitian telah membuktikan bahwa fluorida dapat mencegah terjadinya demineralisasi dan melindungi email gigi [6]. Di Indonesia sendiri, berdasarkan PerMenKes RI Nomor 32 Tahun 2017 Tentang Standar Baku Mutu Kesehatan Lingkungan dan Persyaratan Kesehatan Air untuk Keperluan Higiene Sanitasi, Kolam Renang, Solus Per Aqua, dan Pemandian Umum, menyebutkan bahwa kadar fluorida dalam air adalah $\leq 1,5 \mathrm{mg} / \mathrm{L}$ [7]. Fluorida yang melebihi kadar maksimal dalam air dan jika dikonsumsi dapat mempengaruhi perkembangan kognitif pada anak-anak. Selain itu, apabila fluorida dikonsumsi dalam jumlah yang cukup dapat mencegah timbulnya karies gigi, karang gigi, mencegah gigi berlubang dan bermanfaat untuk kesehatan tulang [8]. Penelitian yang telah dilakukan oleh Aziz dkk [9] menunjukkan bahwa pada konsentrasi $<1,5 \mathrm{mg} / \mathrm{L}$ fluorida sangat bermanfaat bagi kesehatan gigi, pada konsentrasi $>2 \mathrm{mg} / \mathrm{L}$ dapat menyebabkan kerusakan gigi, sedangkan pada konsentrasi 3-6 mg/L dapat menyebabkan kerusakan pada struktur tulang [9]. Kadar fluorida pada air dapat ditentukan dengan berbagai metode salah satunya adalah metode spektrofotometri UV-Vis.

Metode spektrofotometri merupakan suatu teknik analisa spektroskopik menggunakan sumber radiasi elektromagnetik ultraviolet dekat $(190-380 \mathrm{~nm})$ serta sinar tampak $(380-780 \mathrm{~nm})$ dengan menggunakan alat spektrofotometer. Metode ini melibatkan energi elektronik yang cukup besar pada molekul yang dianalisis, sehingga lebih banyak digunakan untuk analisa kuantitatif dibandingkan dengan kualitatif. Beberapa keuntungan dari metode ini yaitu prosedur kerja yang sederhana, hasil yang diperoleh cukup akurat, serta angka yang terbaca langsung dicatat oleh detektor dan menampilkannya dalam bentuk angka digital maupun grafik yang telah diregresikan [10]. 
Berdasarkan uraian di atas, perlu dilakukan pengujian kadar fluorida untuk mengetahui standar baku mutu fluorida pada air sehingga dapat diketahui tingkat pencemarannya. Oleh karena itu, pada penelitian ini dilakukan Analisis Tingkat Pencemaran Air Sungai Berdasarkan Kadar Fluorida Di Kota Mataram Menggunakan Metode Spektrofotometri UV-Vis.

\section{Material dan Metode}

\section{Bahan dan Alat}

Bahan-bahan yang digunakan dalam menunjang penelitian ini yaitu aquades, sampel kontrol fluorida, larutan zirconil alizarin/pereaksi fluorida, larutan $\mathrm{Na}$ arsenit, dan larutan standar fluorida 100 ppm.

Alat-alat yang digunakan dalam penelitian ini yaitu erlenmeyer $100 \mathrm{~mL}$, spektrofotometer UVVis single-beam, pipet tetes, pipet ukur $5 \mathrm{~mL}$, pipet volume $50 \mathrm{~mL}$, labu ukur $50 \mathrm{~mL} \& 100 \mathrm{~mL}$, dan timer.

\section{Metode}

Penelitian ini menggunakan metode spektrofotometri UV-Vis. Penentuan kadar fluorida dilakukan dengan menganalisis hubungan antara absorbansi dan konsentrasi berdasarkan persamaan garis dari hasil pengujian kurva kalibrasi. Kurva kalibrasi bisa digunakan apabila nilai koefisien korelasi $\left(\mathrm{R}^{2}\right)$ yang diperoleh $>0,995$. Standar pengujian yang digunakan dalam penelitian ini berdasarkan Petunjuk Pemeriksaan Air Minum/Air Bersih, Departemen Kesehatan Republik Indonesia. Sampel air sungai diambil di 7 titik lokasi dari 4 sungai yang ada di Kota Mataram dan metode pengambilannya sesuai dengan metode APHA-21-2005. Terdapat tiga sungai masing-masing dua titik lokasi pengambilan serta satu sungai untuk satu titik lokasi pengambilan. Titik lokasi pengambilan yaitu di tepi sungai dan di sekitaran jembatan, berdasarkan pada panjang lintasan sungai yang mengalir melewati pemukiman warga serta aktivitas dan kepadatan populasi di sekitaran sungai. Pengambilan sampel dilakukan dengan tiga kali pengulangan pada setiap titik lokasi sungai. Pengujian dilakukan di Balai Laboratorium Kesehatan, Pengujian dan Kalibrasi Provinsi Nusa Tenggara Barat. Standar baku mutu fluorida yang digunakan berdasarkan PerMenKes RI Nomor 32 Tahun 2017 yaitu tidak boleh melebihi $1,5 \mathrm{mg} / \mathrm{L}$.

\section{Cara Kerja}

\section{Pengujian Kurva Kalibrasi}

Pengujian kurva kalibrasi dimulai dengan melakukan pengenceran larutan standar fluorida 100 ppm sebanyak $10 \mathrm{~mL}$ ke dalam aquades hingga $100 \mathrm{~mL}$. Kemudian, hasil pengenceran tersebut diencerkan lagi untuk mendapatkan larutan standar dengan kadar 0,2;0,4;0,6; 0,8; dan 1,0 ppm dengan melarutkan masing-masing sebanyak 1,$0 ; 2,0 ; 3,0 ; 4,0$; dan 5,0 ppm ke dalam aquades hingga mencapai batas $50 \mathrm{~mL}$. Selanjutnya ditambahkan 2 tetes larutan $\mathrm{Na}$ arsenit dan ditambahkan $5 \mathrm{~mL}$ pereaksi fluorida. Sampel uji didiamkan selama $1 \mathrm{jam}$. Setelah itu, masing-masing sampel diukur absorbansinya menggunakan alat spektrofotometer UV-Vis single-beam dengan panjang gelombang $535 \mathrm{~nm}$. Sebagai blanko nol hanya menggunakan aquades tanpa ditambah pereaksi. Tahap terakhir yaitu dibuat kurva kalibrasinya.

\section{Pengujian Kadar Fluorida}


Adapun langkah-langkah yang dilakukan dalam proses pengujian kadar fluorida yaitu diambil $50 \mathrm{~mL}$ sampel air sungai kemudian dimasukkan ke dalam erlenmeyer. Selanjutnya ditambahkan 2 tetes larutan $\mathrm{Na}$ arsenit dan $5 \mathrm{~mL}$ pereaksi fluorida. Sampel uji didiamkan selama 1 jam kemudian diukur dan dicatat nilai absorbansinya yang terbaca pada spektrofotometer UV-Vis single-beam pada panjang gelombang $535 \mathrm{~nm}$. Sampel air sungai terindikasi fluorida jika terjadi perubahan warna larutan menjadi jingga kecoklatan ketika ditambahkan larutan pereaksi fluorida. Tahap terakhir yaitu dilakukan perhitungan kadar fluorida.

\section{Hasil dan Diskusi}

\section{Pengujian Kurva Kalibrasi}

Kurva kalibrasi merupakan garis yang diperoleh dari gabungan beberapa titik yang menyatakan hubungan antara absorbansi dengan konsentrasi setelah dilakukan analisis regresi secara linear. Kurva kalibrasi harus dibuat dalam rentang konsentrasi sampel. Kurva kalibrasi fluorida ini dibuat dengan cara menghubungkan nilai absorbansi dari lima konsentrasi analit berbeda.

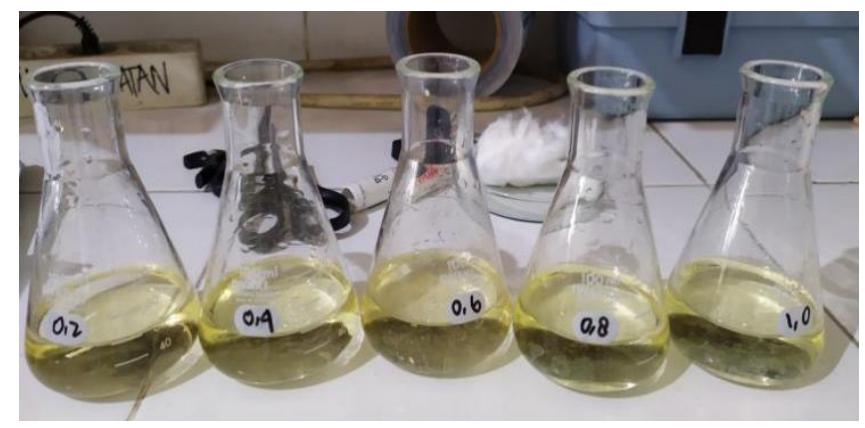

Gambar 1 Larutan Uji Kurva Kalibrasi

Gambar 1 menunjukkan lima sampel larutan standar fluorida untuk pengujian kurva kalibrasi dengan konsentrasi yaitu 0,$2 ; 0,4 ; 0,6 ; 0,8 ;$ dan $1,0 \mathrm{mg} / \mathrm{L}$. Pengujian nilai absorbansi menggunakan spektrofotometer UV-Vis single-beam dengan panjang gelombang $535 \mathrm{~nm}$. Adapun hasil pengujian absorbansinya dijelaskan pada Tabel 1 berikut.

Tabel 1 Hasil Pengujian Absorbansi Kurva Kalibrasi

\begin{tabular}{|c|c|}
\hline Konsentrasi (mg/L) & Absorbansi \\
\hline 0,2 & 0,020 \\
\hline 0,4 & 0,018 \\
\hline 0,6 & 0,016 \\
\hline 0,8 & 0,013 \\
\hline 1,0 & 0,011 \\
\hline
\end{tabular}

Tabel 1 menunjukkan semakin besar konsentrasi larutan standar fluorida maka semakin kecil nilai absorbansinya. Besarnya nilai absorbansi menunjukkan perbandingan logaritmik antara radiasi yang dipaparkan pada suatu cairan terhadap radiasi yang ditransmisikan menembus cairan tersebut. Larutan standar fluorida yang semulanya berwarna putih jernih dan ketika ditambahkan pereaksi zirkonil alizarin yang berwarna merah berubah menjadi jingga disebabkan oleh meningkatnya jumlah 
e-Jurnal Ilmiah BIOSAINTROPIS (BIOSCIENCE-TROPIC)

Volume 7/ No.: 2 / Halaman 119 - 125 / Januari Tahun 2022

ISSN : 2460-9455 (e) - 2338-2805(p)

ion fluorida yang ditambahkan, sehingga menurunkan nilai serapan pada pengamatan di daerah cahaya tampak. Hal tersebut membuat setiap konsentrasi yang berbeda memiliki nilai absorbansi yang berbeda pula. Berdasarkan data hasil pengujian absorbansi yang diperoleh pada Tabel 1, maka diperoleh kurva kalibrasi untuk pengujian kadar fluorida sebagai berikut.

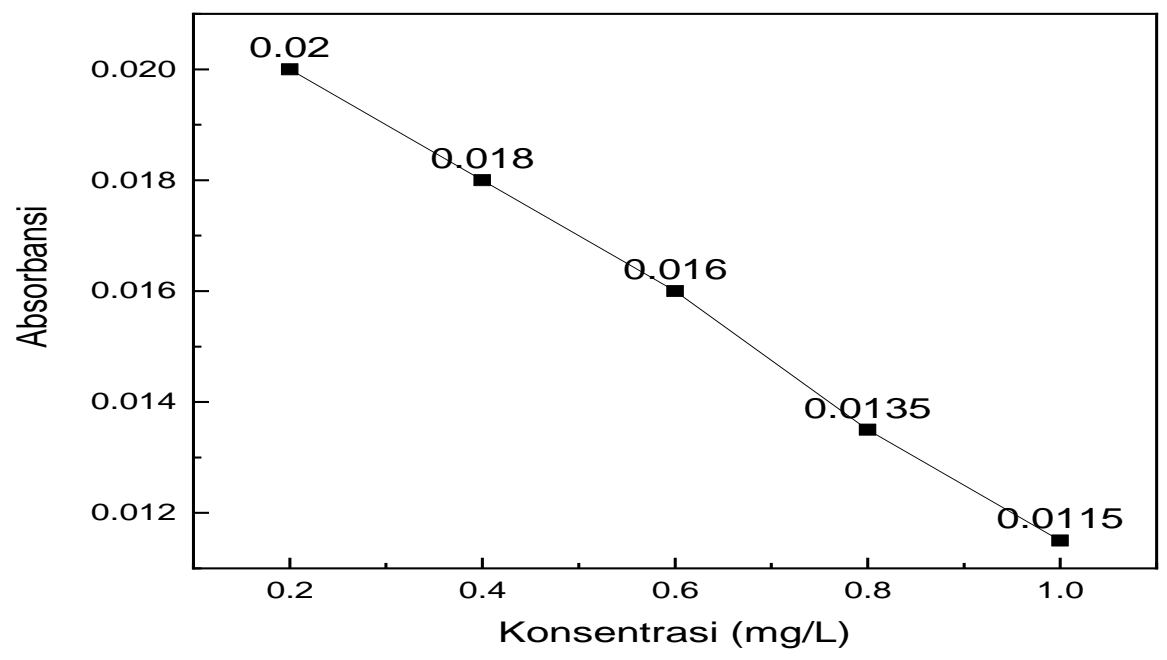

Gambar 2 Kurva Kalibrasi Fluorida

Berdasarkan kurva kalibrasi fluorida pada Gambar 2, diperoleh persamaan garis $y=-0,0108 x$ $+0,0223$ serta nilai koefisien korelasi $\left(\mathrm{R}^{2}\right)$ yang diperoleh sebesar 0,9984 . Koefisien korelasi atau uji kelinearan menyatakan hubungan antara konsentrasi dan absorbansi, ditentukan untuk mengetahui keabsahan kurva kalibrasi yang didapat. Nilai koefisien korelasi yang mendekati +1 menunjukkan linearitas antara konsentrasi dan absorbansinya. Dalam pengujiannya, dilakukan tiga kali pengulangan sehingga diperoleh nilai $\mathrm{R}^{2}$ yang telah memenuhi standar kelinearan garis kurva kalibrasi fluorida. Kurva kalibrasi mengalami penurunan menandakan terjadinya peningkatan konsentrasi fluorida dalam larutan. Semakin tinggi konsentrasi fluorida dapat mengurangi absorbsi kompleks reagen/pereaksi fluorida sehingga dapat menurunkan nilai absorbansinya.

\section{Pengujian Kadar Fluorida}

Pengujian kadar fluorida pada sampel air menggunakan metode Alizarin [11]. Sampel diambil sebanyak $50 \mathrm{~mL}$ kemudian ditambahkan pereaksi asam zirconil alizarin/pereaksi fluorida pada air sebanyak $5 \mathrm{~mL}$ dan larutan 2 tetes larutan $\mathrm{Na}$ arsenit. Pereaksi fluorida pada air dapat digunakan apabila selama 1 jam berubah warna dari merah menjadi warna kuning. Fluorida bereaksi dengan larutan pereaksi (reagen) membentuk kompleks anion tidak berwarna yaitu senyawa zirconium heksafluoride $\left(\mathrm{ZrF}_{6}{ }^{2-}\right)$. Senyawa tersebut yang dilakukan pengujian menggunakan alat spektrofotometer UV-Vis single-beam dengan panjang gelombang sebesar $535 \mathrm{~nm}$. Sampel yang diuji sebanyak 7 sampel dengan 2 larutan fluorida pada air. Adapun hasil pengujiannya dapat dilihat pada Tabel 2 berikut.

Tabel 2 Hasil Uji Kadar Fluorida

\begin{tabular}{|c|c|c|c|}
\hline Kode Sampel & Absorbansi & $\begin{array}{c}\text { Konsentrasi } \\
(\mathrm{mg} / \mathrm{L})\end{array}$ & $\begin{array}{c}\text { Memenuhi Standar } \\
\text { Baku Mutu/Tidak }\end{array}$ \\
\hline Sampel 1 & 0,013 & 0,861 & $\checkmark$ \\
\hline
\end{tabular}


e-Jurnal Ilmiah BIOSAINTROPIS (BIOSCIENCE-TROPIC)

Volume 7/ No.: 2 / Halaman 119 - 125 / Januari Tahun 2022

ISSN : 2460-9455 (e) - 2338-2805(p)

\begin{tabular}{|c|c|c|c|}
\hline Sampel 2 & 0,011 & 1,046 & $\checkmark$ \\
\hline Sampel 3 & 0,013 & 0,861 & $\checkmark$ \\
\hline Sampel 4 & 0,011 & 1,046 & $\checkmark$ \\
\hline Sampel 5 & 0,016 & 0,583 & $\checkmark$ \\
\hline Sampel 6 & 0,020 & 0,213 & $\checkmark$ \\
\hline Sampel 7 & 0,020 & 0,213 & $\checkmark$ \\
\hline CC1 & 0,021 & 0,120 & $\checkmark$ \\
\hline CC2 & 0,021 & 0,120 & $\checkmark$ \\
\hline
\end{tabular}

Keterangan :

$\mathrm{CC} 1=$ Sampel Kontrol 1

$\mathrm{CC} 2=$ Sampel Kontrol 2

Berdasarkan Tabel 2 diperoleh kadar fluorida dari 7 sampel yang diuji telah memenuhi standar baku mutu fluorida berdasarkan Peraturan Menteri Kesehatan Republik Indonesia No. 492/Menkes/Per/IV/2010 [12] yaitu 1,5 mg/L. Air sungai tersebut dapat digunakan untuk keperluan hygiene sanitasi, kolam renang, solus per aqua, dan pemandian umum karena memenuhi fluorida baku mutu. Besarnya kadar fluorida beragam dari berbagai sungai. Kadar fluorida tertinggi terdapat pada sampel 2 dan sampel 4 sebesar 1,046 mg/L, sedangkan kadar fluorida terendah terdapat pada sampel 6 dan sampel 7 sebesar $0,213 \mathrm{mg} / \mathrm{L}$. Tinggi rendahnya kadar fluorida pada air bergantung pada proses ekstraksi air tanah, penggunaan bahan kimia dan pestisida, dan morfologi geografis suatu tempat.

\section{Kesimpulan}

Berdasarkan hasil penelitian dan analisis data dari 7 titik lokasi pengambilan sampel air sungai dapat disimpulkan bahwa sungai di Kota Mataram tidak tercemar fluorida.

\section{Ucapan Terima Kasih}

Ucapan terima kasih penulis sampaikan kepada semua pihak yang telah berkontribusi dalam menyelesaikan penelitian dan publikasi jurnal ini, terkhusus kepada Balai Laboratorium Kesehatan, Pengujian dan Kalibrasi Provinsi Nusa Tenggara Barat atas ketersediaan menjadi tempat pengujian serta kepada Dosen Pembimbing atas arahan dan bimbingannya selama ini.

\section{Daftar Pustaka}

[1] Badan Pusat Statistik Kota Mataram. 2020. Produktivitas Kangkung 2018-2020. Diakses pada tanggal $02 \quad$ Desember $2021 . \quad$ URL: https://mataramkota.bps.go.id/indicator/55/217/1/produktivitas-kangkung.html 
e-Jurnal Ilmiah BIOSAINTROPIS (BIOSCIENCE-TROPIC)

Volume 7/ No.: 2 / Halaman 119 - 125 / Januari Tahun 2022

ISSN : 2460-9455 (e) - 2338-2805(p)

[2] Wiriani, E. R. 2018. Analisis Kualitas Air Sungai Batanghari Berkelanjutan Di Kota Jambi. Jurnal Pembangunan Berkelanjutan, 1(1): 123-141. Diterima tanggal 28 November 20211. Doi: https://doi.org/10.22437/jpb.v1i2.5415

[3] Departemen Kesehatan RI. 2001. Peraturan Pemerintah Republik Indonesia No. 82 Tahun 2001 tentang Pengelolaan Kualitas dan Air Pengendalian Pencemaran Air. Diterima tanggal 28 November 2021. URL: https://luk.staff.ugm.ac.id/atur/sda/PP822001PengelolaanKualitasAir.pdf

[4] Gafur, A., Kartini, A. D., dan Rahman. 2017. Studi Kualitas Fisik Kimia dan Biologis pada Air Minum Dalam Kemasan Berbagai Merek yang Beredar di Kota Makassar Tahun 2016. Higiene: Jurnal Kesehatan Lingkungan, 3(1):37-46.

[5] Triwuridan, N.A., dan Hazimah. 2018. Kadar Fluorida dalam Air Minum Isi Ulang Di Kota Batam. Jurnal Rekayasa Sistem Industri, 4(1):1-5. ISSN (print) 2477-2089 (online) 2621-1262.

[6] Novita, C. F., Herwanda, M., dan Auzan, F. 2015. Gambaran Tingkat Pengetahuan Tentang Fluorida pada Masyarakat Kota Banda Aceh pada Tahun 2015, Cakradonya Dent J. 10(1):53-58.

[7] Departemen Kesehatan RI. 2017. Peraturan Menteri Kesehatan RI No. 32 Tahun 2017 tentang Standar Baku Mutu Kesehatan Lingkungan dan Persyaratan Kesehatan Air. Diterima tanggal 28 November $2021 . \quad$ URL: http://hukor.kemkes.go.id/uploads/produk hukum/PMK No. 32 ttg_Standar Baku Mutu Kesehatan Air Keperluan Sanitasi, Kolam Renang, Solus Per Aqua.pdf

[8] Najib, C.A.M., dan Nuzlia, C. 2019. Uji Kadar Fluorida Pada Air Minum dalam Kemasan (AMDK) dan Air Sumur Secara Spektrofotometri UV-Vis. AMINA, 1(2):84-90.

[9] Aziz, T., Pratiwi, D. Y., dan Rethiana, L. 2013. Pengaruh Penambahan Tawas $\mathrm{Al}_{2}\left(\mathrm{SO}_{4}\right)_{3}$ dan Kaporit $\mathrm{Ca}(\mathrm{Ocl})_{2}$ Terhadap Karakteristik Fisik dan Kimia Air Sungai Lambidaro. Jurnal Teknik Kimia, 19(3):55-65.

[10] Putri, L. E. 2017. Penentuan Konsentrasi Senyawa Berwarna $\mathrm{KmnO}_{4}$ dengan Metode Spektroskopi UV Visible. Natural Science Journal, 3(1):391-398.

[11] Badan Standarisasi Nasional. 1991. Metode Pengujian Kadar Sianida Dalam Air dengan Alat Ion Selektif Meter. Diterima tanggal 10 Januari 2022. URL: https://pustaka.pusairpu.go.id/index.php?p=fstream-pdf\&fid=426\&bid=595

[12] Departemen Kesehatan RI. 2010. Peraturan Menteri Kesehatan RI tentang Persyaratan Kualitas Air Minum No. 492/MENKES/PER/IV/2010. Diterima tanggal 28 November 2021. URL: $\quad$ https://stunting.go.id/kemenkes-permenkes-no-492-tahun-2010-tentangpersyaratan-kualitas-air-minum/ 